International Research Journal of Diabetes and Metabolism
(ISSN:2637-6717)

\title{
The Two-way Street between Periodontal Diseases and Diabetes
}

\section{Renata Cimões ${ }^{1}$, Roberto Carlos Mourão Pinho ${ }^{2}$}

${ }^{1}$ Associate Professor of the Department of Prosthesis and Buco-Facial Surgery at UFPE; PostDoctorate in Periodontics Eastman Dental Institute, London. PhD in Dentistry; Specialist in Periodontics; ITI Fellow, Speaker and Study Club Director;

${ }^{2}$ Post-Doctorate in Dentistry UFPE; PhD in Dentistry UFPE; Specialist in Dentistry for Patients with Special Needs; Specialist in Endodontics; Molecular Biology Specialist

Periodontitis is a chronic inflammatory disease that is initiated by the accumulation of dental biofilm, where dysbiosis leads to a chronic non-resolving condition, and destructive inflammatory response. The destruction of tissues that we clinically recognize as periodontitis (that is, destruction of the periodontal ligament, periodontal pocket formation and alveolar bone resorption) is caused mainly by the host's inflammatory response to the bacterial challenge presented by the biofilm ${ }^{[38]}$.

Periodontitis affects, in its severe forms, approximately $10 \%$ of the global population, which represents almost 750 million people worldwide[16]. The prevalence of periodontitis among all adults aged 30 years and over registered by the National Health and Nutrition Examination Survey (NHANES) in the United States is $\left.46 \%{ }^{8}\right]$. In addition, periodontitis has been found to be more severe and 3 times more likely to occur in patients with diabetes mellitus (DM) compared to the general population ${ }^{[14,25]}$, and the level of glycemic control is the key to determining risk, and similar to other diabetes complications, the risk of periodontitis increases with a worse glycemic index ${ }^{[3]}$.

DM, a chronic non-communicable metabolic disease, occurs when blood glucose levels are increased, or because the body cannot produce any, or enough insulin, or use insulin effectively [15].
*Correspondence to Author:

Renata Cimões

Associate Professor of the Department of Prosthesis and Buco-Facial Surgery at UFPE; Post-Doctorate in Periodontics Eastman Dental Institute, London. PhD in Dentistry; Specialist in Periodontics; ITI Fellow, Speaker and Study Club Director;

How to cite this article:

Renata Cimões, Roberto Carlos Mourão Pinho. The Two-way Street between Periodontal Diseases and Diabetes. International Research Journal of Diabetes and Metabolism, 2021, 4:18.

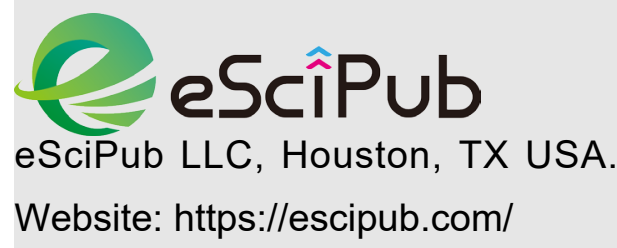




\section{DIABETES AND PERIODONTITIS}

Periodontal disease is considered the sixth most common classic complication of diabetes (LÖE, 1993), and is the most significant oral complication (BROWN and LÖE, 1993) ${ }^{[4]}$. The total surface area of inflamed and ulcerated periodontal tissues of an individual with periodontitis has been estimated to be equivalent to the surface area of the palm (PAGE, 1998) ${ }^{[29]}$, demonstrating the potential for production of inflammatory mediators by periodontal disease.

As diabetes is considered one of the biggest risk factors for periodontitis (GENCO and BORGNAKKE, 2013; LÖE, 1993) ${ }^{[10]}$, individuals with this chronic metabolic disease are more likely to have periodontitis and have an increase in severity when diabetes is considered uncontrolled (BROWN and LÖE, 1993) ${ }^{[4]}$, so if early diagnosis of prediabetes and early diabetes are treated effectively, it is possible that the progression of hyperglycemia could also be prevented or delayed, which may eventually lead to reduced progression of periodontitis (PHILLIPS, RATNER, BUSE and KAHN, 2014) [31]. On the other hand, aging is associated with a progressive decline in glucose tolerance, which coincides with the increased prevalence of periodontitis in this age group, thus, the increase in life expectancy predicts an increase in periodontitis worldwide, with variations between different populations (KASSEBAUM et al., 2014) [16]. This prediction should mobilize attention for continuous oral health care from the moment of diagnosis of both diseases.

Periodontitis and Type 2 Diabetes Mellitus (DM2) are important health problems, especially in low-income populations with limited access to dental care. They are chronic diseases with epidemiological evidence that point to a bidirectional relationship between the two, that is, one influencing the other (LÖE, 1993) [21]. Therefore, there is strong evidence for the association between periodontitis and diabetes both in relation to glycemic control and in relation to microvascular complications resulting from
DM2, which also show associations with severe periodontitis, related to micro and macro angiopathies. (MAPANGA e ESSOP, 2018) [23].

Periodontitis and diabetes establish a two-way street, and each, if left untreated, could promote or exacerbate one another. Periodontal screening should be part of the general clinical examination of patients with diabetes and, if diagnosed, periodontal disease should be treated appropriately to prevent or exacerbate diabetes, also improving glycemic control in these individuals. (NAIFF, CARNEIRO, GUIMARÃES, 2018) [27].

Adults aged 45 and over with poorly controlled diabetes (HbA1c> $9 \%$ ) were 2.9 times more likely to have severe periodontitis than those without diabetes. The likelihood is even greater (4.6 times) among smokers with poorly controlled diabetes, and about a third of people with diabetes have severe periodontal disease consisting of loss of insertion (5 millimeters or more) (CDC, 2011) ${ }^{[5]}$.

Both periodontitis and diabetes are chronic diseases caused by inflammation, which often occur mutually and adversely in the same individuals, one affecting the other. Risk factors for both diseases include older age, male gender, ethnicity, low socioeconomic status, genetic predisposition (mainly for immune and inflammatory responses), smoking, obesity, low level of physical activity and unhealthy diet (KOCHER et al, 2018) ${ }^{[18] .}$

In addition, studies have suggested that periodontitis can promote changes in the quality of life of these individuals (PINHO et al., 2018) [35], possibly be related to the higher prevalence of depression (HASHIOKA et al., 2018) ${ }^{[12]}$, and also that the presence of severe periodontitis may be associated with the incidence of mild cognitive impairment among the elderly (IWASAKI et al., 2018) ${ }^{[13] .}$

Both diabetes and periodontitis are associated with inflammation and impaired immune responses (DIAS et al., 2018) ${ }^{[34-36]}$. Changes in biological defense markers (PINHO et al., 2018) 
[34-36] in biological markers for Vitamin D (PINHO et al., 2018) [34-36], high levels of systemic inflammatory cytokines, such as interleukin1 beta and interleukin-6, and the marker inflammatory acute phase, reactive protein $\mathrm{C}$, are consistently observed in DM2, as well as in periodontitis (LIU et al., 2016) [20], in addition to reactive oxygen species (ROS) that can interfere in the metabolic control of diabetes and act synergistically in the worsening of the diabetes (PENG et al., 2017) ${ }^{[30] .}$

According to Akazawa (2018) ${ }^{[1]}$, the association between glycemic control and periodontal conditions, although there are positive relationships, where DM evokes a hyper inflammatory response to aggression to the periodontium and impairs the repair process, leading to exaggeration of periodontal destruction. These processes are partially mediated by advanced glycation end products (AGEs) and the AGE receptor (RAGE). Catelicidin, which is an antimicrobial peptide, and annexin decrease in DM2 (MARINHO et al., 2019) [24], as well as the activation of proinflammatory cytokines in the periodontium, where the levels of IL-1 $\beta$, IL- 6 and activator of the nuclear factor $\mathrm{KB}$ ligand (RANKL)/osteoprotegerin (OPG), IL-17 receptor that operates in conjunction with other inflammatory cytokines, where a general deregulation can contribute to promote changes that the microbial dysbiosis of these mediators in the host (GRAVES, CORRÊA and SILVA, 2019) [11], IL-4 (KSIAZEK, BLASZCZAK and BURACZYNSKA, 2019) [19], IL-8 (BORILOVA et al., 2019) ${ }^{[3]}$ and matrix metalloproteinase (MMP, "extracellular matrix metalloproteinases") (particularly MMP-8, MMP-9 and MMP-13) are elevated in patients with periodontitis that are complicated with DM compared to patients with periodontitis only (AKAZAWA, 2018) ${ }^{[1]}$.

It has been proposed that type 2 diabetes is a manifestation of the host's inflammatory response, because a constant cytokine-induced acute phase response is closely involved in the pathogenesis of this disease and its associated complications, such as dyslipidemia and atherosclerosis (PICKUP, 2004) [32]. This cytokine-induced response is of low inflammation that occurs through the activation of the innate immune system. Increased serum concentrations of acute phase response markers and cytokines have been observed in patients with type 2 diabetes, indicating that circulating inflammatory cytokines modify the risk for type 2 diabetes (SPRANGER et al., 2003) ${ }^{[42]}$. Likewise, the mechanisms of the hostmediated response in periodontal disease involve activation of the broad axis of innate immunity, specifically by the positive regulation of pro-inflammatory cytokines of monocytes and polymorphonuclear leukocytes, in the presence of gram-negative sub gingival bacterial biofilm (NASSAR, KANTARCI, VAN DYKE, 2007) [28]. Thus, chronic gram-negative periodontal infections can induce or perpetuate an elevated chronic systemic inflammatory state, contributing to increased insulin resistance and poor glycemic control. (MEALEY and OATES, 2007; TUNES et al., 2010) ${ }^{[25,44]}$ (Figure 1).

The first attempt to explore more proximal changes induced by diabetes mellitus that could explain the hyper inflammatory response to infection seen in the initial studies, focused on the role of the receptor for advanced glycation end products (RAGE), a signaling receptor and member of the immunoglobulin superfamily cell surface molecules (DEL TURCO and BASTA, 2012) ${ }^{[6]}$. The expression of RAGE is increased in patients with $\mathrm{DM}$, and its activation through interaction with its ligands has an established role in the development and progression of other diabetic complications, firstly, the expression of RAGE binds to advanced glycation end products (AGEs) and oxidative stress markers, and was demonstrated in the gingival tissues of patients who had diabetes mellitus and periodontitis. Subsequently, serum AGEs levels were shown to be associated with the extension of periodontitis in adults with type $2 \mathrm{DM}$, and increased RAGE expression was observed in 
the gingival tissues of individuals with diabetes mellitus and periodontitis (KATZ et al., 2005) ${ }^{[17]}$. Attempts have been made to demonstrate the effect of periodontal treatment on glycemic control of DM, and there seems to be good evidence to support this hypothesis, since studies have been conducted that show an improvement in both clinical and immunological parameters of periodontitis, as well as in longterm glycemic control of DM after periodontal disease treatment (FARIA-ALMEIDA, NAVARRO and BASCONES, 2006) ${ }^{[9]}$.

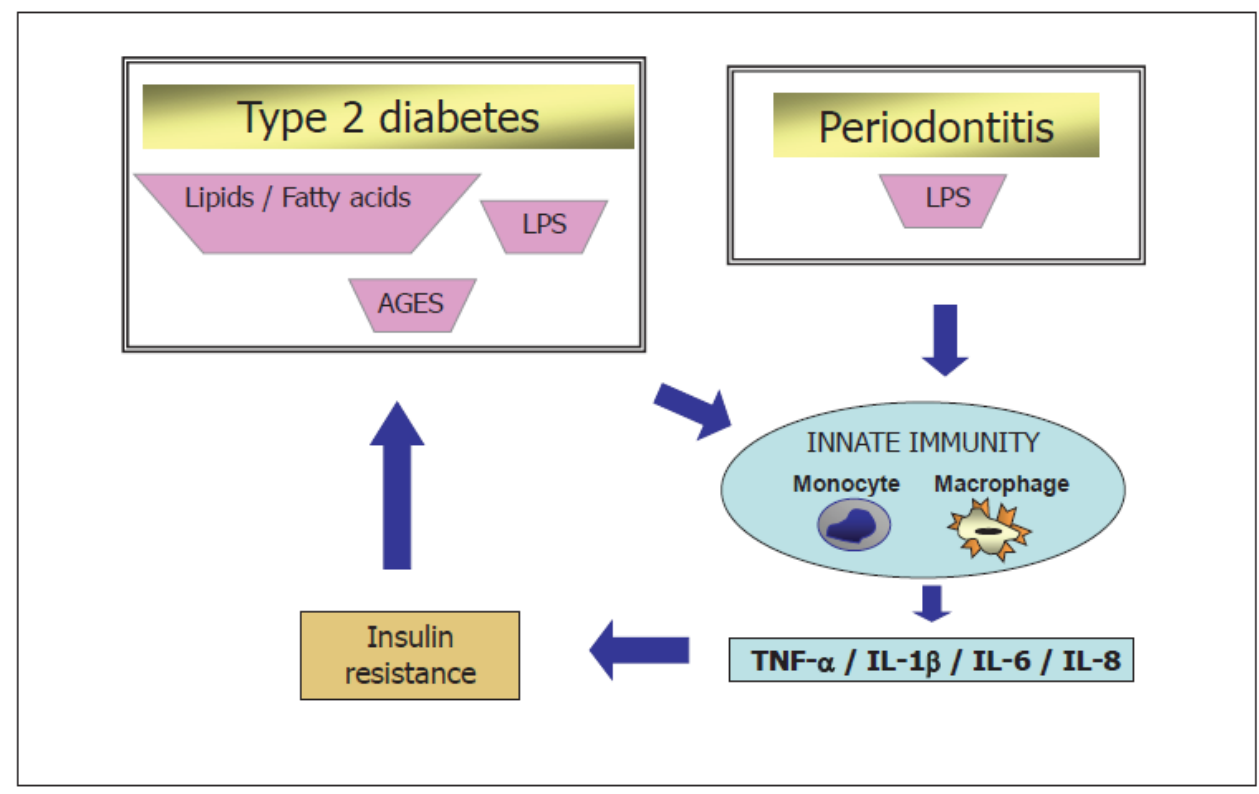

Figure 1. Innate immunity, periodontitis and diabetes mellitus (Source: Based on TUNES, R.S.; FOSS-FREITAS, M.C.; NOGUEIRA-FILHO, G.R. Impact of periodontitis on the diabetes-related inflammatory status. J Can Dent Assoc. vol. 76, 2010, p. a35).

Although there are studies in which they have not been able to find a strong association, and there are few randomized clinical trials, it is currently considered that the existing evidence is sufficient to justify investigating the effects of treatment and prevention of periodontitis as a path that would contribute to improve metabolic control in diabetic patients. In addition, there are authors who point out that prevention and control of periodontal disease should be considered as an integral part of DM control. (TEEUW et al., 2010) ${ }^{[43]}$.

Periodontal therapeutic intervention can help reduce the risk of cardiovascular complications in patients with diabetes. Adequate dental management should be suggested to improve the health conditions of diabetic patients (PENG et al., 2017) ${ }^{[30]}$. Non-surgical periodontal therapy involves the removal of bacterial agents from the periodontium, supra and sub gingival calculus, root smoothing and polishing, using curettes or ultrasonic devices. This is the conventional treatment for periodontitis to resolve inflammation of periodontal tissues and, consequently, disease control (SANTOS et al., 2009) ${ }^{[41] .}$

The conventional non-surgical approach, which consists of several partial scraping and straightening sessions by root quadrants alone or in combination with adjuvant therapies at intervals of 1 to 3 weeks, which has resulted in clinical improvements in patients with DM2 (SANTOS et al., 2009) [41]. Another modality consists of treatment through scaling and root smoothing of the whole mouth in a single session (SABHARWAL et al., 2018) ${ }^{[40]}$ with or without adjuvant use of chlorhexidine (APATZIDOU, RIGGIO and KINANE, 2004) [2]. This intensive protocol has been proposed to reduce the probability of bacterial translocation 
of untreated periodontal pockets to those already treated and has demonstrated clinical and microbiological results similar or superior to those of the conventional quadrant approach, however, the periodontal treatment of the entire mouth in a single session was not considered superior to the treatment by quadrants in patients with uncontrolled DM2, but there was an improvement in the levels of glycated hemoglobin and in the periodontal clinical parameters in both non-surgical treatment modalities (QUINTERO et al., 2018) ${ }^{[39]}$ and quality of life of these people (NAIFF, CARNEIRO and GUIMARÃES, 2018) [27].

A study conducted by Lucena et al., (2017) [22], with the objective of assessing metabolic control and comparing the clinical effects between nonsurgical and surgical therapies in the periodontal treatment of residual bags of patients with DM2, reported that the mean values of $\mathrm{Hb} 1 \mathrm{Ac}$ of patients were significantly reduced after surgical and non-surgical periodontal therapy, where both behaved similarly when compared to each other, but with greater effectiveness of surgical therapy in reducing the studied clinical parameters. The precise mechanisms that lead to $\mathrm{HbA} 1 \mathrm{c}$ reduction and improved glycemic control after periodontal treatment in people with diabetes are not completely clear, but are presumed to arise from the combined effects of reduced systemic inflammation and reduced systemic bacterial challenge, leading to improvements in insulin resistance and insulin signaling (POLACK and SHAPIRA, 2018) ${ }^{[37]}$.

Potential link mechanisms between periodontitis and diabetes and the impact of periodontal therapy on diabetes control. In untreated periodontitis, bacteria and bacterial antigens, together with pro-inflammatory mediators and cytokines, enter the circulation and contribute to an over-regulated systemic inflammatory state. This results in insufficient insulin signaling and increased insulin resistance, leading to elevated levels of $\mathrm{HbA1C}$ and increased complications from diabetes. After periodontal therapy and reductions in periodontal inflammation, there are reduced levels of circulating bacteria and antigens and reduced circulating levels of cytokines and inflammatory mediators. This results in a reduction in the systemic inflammatory state, leading to better insulin signaling and less (improved) insulin resistance. In turn, there is a reduction in $\mathrm{HbA} 1 \mathrm{c}$, better control of diabetes and fewer complications of diabetes (POLACK and SHAPIRA, 2018; PRESHAW and BISSETT, 2019) ${ }^{[37,38]}$. (Figure 2).
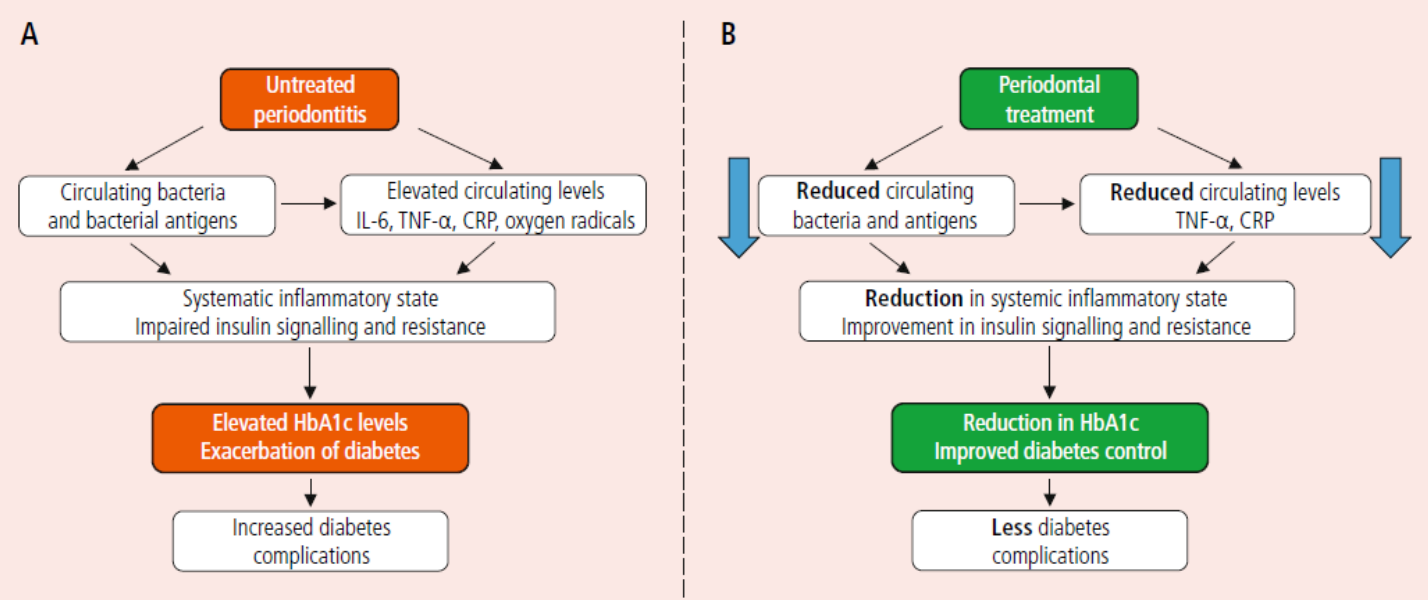

Figure 2 - Adapted from POLAK, D.; SHAPIRA, L. An update on the evidence for pathogenic mechanisms that may link periodontitis and diabetes. J Clin Periodontol, vol. 45, 2018, p. 150-166 and from PRESHAW P.M.; BISSETT, S.M. Periodontitis and diabetes [J]. British dental journal, vol. 227, n. 7, 2019, p. 577-584. 
A: In untreated periodontitis, bacteria and bacterial antigens, together with proinflammatory mediators and cytokines, enter the circulation and contribute to an over-regulated systemic inflammatory state. This results in insufficient insulin signaling and increased insulin resistance, leading to elevated levels of $\mathrm{HbA1C}$ and increased complications from diabetes.

B: After periodontal therapy and reductions in periodontal inflammation, there are reduced levels of circulating bacteria and antigens and reduced circulating levels of cytokines and inflammatory mediators. This results in a reduction in the systemic inflammatory state, leading to better insulin signaling and less (improved) insulin resistance. In turn, there is a reduction in $\mathrm{HbA1c}$, better control of diabetes and fewer complications of diabetes.

Caption: CRP, C-reactive protein; HbA1c, glycated hemoglobin; IL-6, interleukin-6; TNF- $\alpha$, Tumor Necrosis Factor- $\alpha$.

\section{FINAL CONSIDERATIONS}

Both DM and periodontitis, because they are chronic diseases, require frequent monitoring and constant stimulation and reinforcement for the patient so that their control can be achieved satisfactorily, but as an early stage and prediabetes can be a predictor of periodontitis that you can start right away, this monitoring must be performed earlier so that it can assist in glycemic control and also prevent tooth loss, which happens with the progression of the disease and which leads to a reduction in the quality of life in the affected individuals.

Non-surgical and surgical periodontal treatment are part of a protocol of interventions that reduce the microbiota and inflammatory cytokines, responsible for the destruction of the supporting tissues of the teeth, and therefore, when performed together with an effective oral hygiene instruction program for diabetic patients, oral health in these individuals will be achieved.

\section{REFERENCES}

[1]. AKAZAWA, H. Periodontitis and Diabetes Mellitus: Be true to your teeth. Int Heart J, vol. 59, n. 4, 2018, p. 680-682. doi:10.1536/ihj.18410.

[2]. APATZIDOU, D.A.; RIGGIO, M.P.; KINANE, D.F. Quadrant root planing versus same-day full-mouth root planing. II. Microbiological findings. J Clin Periodontol, vol. 31, n. 2, 2004, p. 141-148. doi:10.1111/j.03036979.2004.00462.x.

[3]. BORILOVA LINHARTOVA, P.; KAVRIKOVA, D.; TOMANDLOVA, M., et al. Differences in Interleukin-8 Plasma Levels between Diabetic Patients and Healthy Individuals Independently on Their Periodontal Status. Int J Mol Sci, vol. $19, \quad$ n. $10, \quad 2018, \quad$ p. 3214. doi:10.3390/ijms19103214.

[4]. BROWN, L.J.; LÖE, H. Prevalence, extent, severity and progression of periodontal disease. Periodontol 2000, vol. 2, 1993, p. 57-71.

[5]. CDC Centers for Disease Control and Prevention. National diabetes fact sheet: national estimates and general information on diabetes and prediabetes in the United States, 2011. Atlanta, GA: U.S. Department of Health and Human Services $C$ for $D C$ and $P$ http://www.cdc.gov/diabetes/pubs/pdf/ndfs_201 1.pdf. (2011). National Diabetes Fact Sheet, 2011. Atlanta; 2011. Available from: http://www.cdc.gov/.

[6]. DEL TURCO, S.; BASTA, G. An update on advanced glycation endproducts and atherosclerosis. Biofactors, vol. 38, n. 4, 2012, p. 266-274. doi:10.1002/biof.1018.

[7]. DIAS, R.S.A.M.; PINHO, R.C.M.; ALMEIDA F.R.; CELERINO; R., CIMÕES; R., et al. Evaluation of DEFB1 polymorphisms in individuals with chronic periodontitis and diabetes mellitus type 2 in a population of northeastern Brazil. Special Care in Dentistry, vol. 38, n. 4, 2018, p. 227-233. doi:10.1111/scd.12296.

[8]. EKE, P.I.; DYE, B.A.; WEI, L.; SLADE, G.D.; THORNTON-EVANS, G.O.; BORGNAKKE, W.S.; et al. Update on Prevalence of Periodontitis in Adults in the United States: NHANES 2009 to 2012. J Periodontol, vol. 86, n. $5, \quad 2015, \quad$ p. 611-22. https://doi.org/10.1902/jop.2015.140520.

[9]. FARIA-ALMEIDA, R.; NAVARRO, A.; BASCONES, A. Clinical and metabolic changes after conventional treatment of type 2 diabetic patients with chronic periodontitis. J Periodontol, vol. 77, n. 4, 2006, p. 591-598. doi:10.1902/jop.2006.050084. 
[10]. GENCO, R.J.; BORGNAKKE, W.S. Risk factors for periodontal disease. Periodontol 2000, vol 62, n. 1, 2013, p. 59-94.

[11]. GRAVES, D.T.; CORRÊA, J.D.; SILVA, T.A. The Oral Microbiota Is Modified by Systemic Diseases, vol. 98, n. 2, 2019, p. 148-156. doi:10.1177/0022034518805739.

[12]. HASHIOKA, S.; INOUE, K.; HAYASHIDA, M.; WAKE, R.; OH-NISHI, A. Implications of Systemic Inflammation and Periodontitis for Major Depression, vol. 12, July, 2018, p. 1-7.

[13]. IWASAKI, M.; KIMURA, Y.; OGAWA, H.; YAMAGA, T.; ANSAI, T.; WADA, T., et al. Periodontitis, periodontal inflammation, and mild cognitive impairment: A 5-year cohort study. Journal of Periodontal Research, 2019, 54(3), 233-240.

[14]. IZUORA, K.; YOUSIF, A.; ALLENBACK, G.; GEWELBER, C.; NEUBAUER, M. Relationship between dental loss and health outcomes among hospitalized patients with and without diabetes. Journal of Investigative Medicine, vol. 67 , n. 3, 2019, p. 669-673.

[15]. KALAITZOGLOU, E.; FOWLKES, J.L.; POPESCU, I.; THRAILKILL, K.M. Diabetes pharmacotherapy and effects on the musculoskeletal system. Diabetes/metabolism research and reviews, vol. 35, n. 2, 2019, p. e3100.

[16]. KASSEBAUM, N. J.; BERNABÉ, E.; DAHIYA, M.; BHANDARI, B.; MURRAY, C. J. L.; MARCENES, W. Global burden of severe periodontitis in 1990-2010: A systematic review and meta-regression. Journal of Dental Research, vol. 93, 2014, p. 1045-1053. https://doi.org/10.1177/0022034514552491.

[17]. KATZ, J.; BHATTACHARYYA, I.; FARKHONDEH-KISH, F.; PEREZ F.M.; CAUDLE R.M.; HEFT M.W. Expression of the receptor of advanced glycation end products in gingival tissues of type 2 diabetes patients with chronic periodontal disease: a study utilizing immunohistochemistry and RT-PCR. J Clin Periodontol, vol. 32, n. 1, 2005, p. 40-44. doi:10.1111/j.1600-051X.2004.00623.x.

[18]. KOCHER, T.; KÖNIG, J.; SYLLING, W.; CHRISTIANE, B.; MEISEL, P.; KOCHER, T. Periodontal complications of hyperglycemia/diabetes mellitus: Epidemiologic complexity and clinical challenge. Periodontology 2000. 2018, p. 59-97.

[19]. KSIAZEK, K.; BLASZCZAK, J.; BURACZYNSKA, M. IL4 gene VNTR polymorphism in chronic periodontitis in endstage renal disease patients. Oral Dis., vol. 25, n. 1, 2019, p. 258-264. doi:10.1111/odi.12974.
[20]. LIU, C.; FENG, X.; LI, Q.; WANG, Y.; LI, Q.; HUA, M. Adiponectin, TNF- $\alpha$ and inflammatory cytokines and risk of type 2 diabetes: $A$ systematic review and meta-analysis. Cytokine, vol. 86, 2016, pp. 100-109. doi:10.1016/j.cyto.2016.06.028.

[21]. LÖE, H. Periodontal Disease. The sixth complication of diabetes mellitus. Diabetes Care, vol. 16, n.1, 1993, p. 329-34.

[22]. LUCENA, K.; LIMA JUNIOR, S.; RIBEIRO, I.; CIMÕES, R.; CARVALHO, A. Clinical and Metabolic Effects of two Periodontal Therapeutic Modalities in Diabetic Patients with Residual Pockets. Pesqui Bras Odontopediatria Clin Integr, vol. 17, n. 1, 2017, p. e2577. http://dx.doi.org/10.4034/PBOCl.2017.171.02.

[23]. MAPANGA, R.F.; ESSOP, M.F. Damaging effects of hyperglycemia on cardiovascular function: spotlight on glucose metabolic pathways. Am J Physiol Circ Physiol, v. 310, n. 2, 2016, p. H153-73.

[24]. MARINHO, M.C.; PACHECO, A.B.F.; COSTA, G.C.V.; ORTIZ, N.D.; ZAJDENVERG, L.; SANSONE C. Quantitative gingival crevicular fluid proteome in type 2 diabetes mellitus and chronic periodontitis. Oral Dis., vol. 25, n. 2, 2019, p. 588-595. doi:10.1111/odi.12996.

[25]. MEALEY, B.L.; OCAMPO, G.L. Diabetes mellitus and periodontal disease. Periodontol 2000, vol. 44, 2007, p. 127-153.

[26]. MEALEY, B.L.; OATES, T.W.; AMERICAN ACADEMY OF PERIODONTOLOGY. Diabetes mellitus and periodontal diseases. J Periodontol, vol. 77, n. 8), 2006, p. 1289-1303. doi:10.1902/jop.2006.050459.

[27]. NAIFF, P.; CARNEIRO, V.; GUIMARÃES, M. DO C. Importance of Mechanical Periodontal Therapy in Patients with Diabetes Type 2 and Periodontitis. Int J Dent, 2018, 2018, p.1-7.

[28]. NASSAR, H.; KANTARCI, A.; VAN DYKE, T.E. Diabetic periodontitis: a model for activated innate immunity and impaired resolution of inflammation. Periodontol 2000, vol. 43, 2007, p. 233-44. doi: 10.1111/j.16000757.2006.00168.x. PMID: 17214841; PMCID: PMC2034354.

[29]. PAGE, RC. The Pathobiology of Periodontal Diseases May Affect Systemic Diseases: Inversion of a Paradigm. Ann Periodontol, vol. 3, n. 1, 1998, 108-20.

[30]. PENG, C.H.; YANG, Y.S.; CHAN, K.C.; KORNELIUS, E.; CHIOU, J.Y.; HUANG, C.N. Periodontal Treatment and the Risks of Cardiovascular Disease in Patients with Type 2 Diabetes: A Retrospective Cohort Study. Intern 
Med, vol. 56, vol. 9, 2017, p. 1015-1021. doi:10.2169/internalmedicine.56.7322.

[31]. PHILLIPS, L.S.; RATNER, R.E.; BUSE, J.B.; KAHN, S.E. We can change the natural history of type 2 diabetes. Diabetes Care, vol. 37, n. 10, 2014, p. 2668-76.

[32]. PICKUP, J.C. Inflammation and activated innate immunity in the pathogenesis of type 2 diabetes. Diabetes Care, vol. 27, n. 3, 2004, p. 813-823. doi:10.2337/diacare.27.3.813.

[33]. PIHLSTROM B. L, MICHALOWICZ B. S, JOHNSON N. W. Periodontal diseases. Lancet 2005; 366: 1809-1820.

[34]. PINHO, R.C.M.; DIAS, R.S.A.M.; BANDEIRA, F., CIMÕES R. et al. Polymorphisms of the vitamin $D$ receptor gene (FOKI, CDX2, and GATA) and susceptibility to chronic periodontitis in diabetic and non-diabetic individuals: A casecontrol study. J Investig Clin Dent, vol. 10, n. 1, 2019, p. e12370. doi:10.1111/jicd.12370.

[35]. PINHO, R.C.M.; DE MELO DIAS, R.S.A.; BANDEIRA, F.; DA SILVA BARBOSA, A. C.; JÚNIOR, A. D.F.C.; CIMÕES, R. Impact of Chronic Periodontitis on the Quality of Life of Individuals with and without Diabetes. Health Science Journal, vol. 12, n. 2, 2018, p. 1-11.

[36]. PINHO, R.C.M.; DIAS, R.S.A.M.; RODRIGUES, J.K.F.; DOS SANTOS, E.U.D.; LUNA, G.M.; CIMÕES, R. Single Nucleotide Polymorphism (Rs4804803) in the DC-SIGN Promoter Region Cd209 and Implications Regarding the Susceptibility to Chronic Periodontitis in Individuals with Type 2 Diabetes Mellitus. Health Sci J, vol. 12, n. 4, 2018, p. 580. DOI: 10.21767/1791-809X.1000580.

[37]. POLAK, D.; SHAPIRA, L. An update on the evidence for pathogenic mechanisms that may link periodontitis and diabetes. $\mathrm{J}$ Clin Periodontol, vol. 45, n. 2, 2018, p. 150-166. doi:10.1111/jcpe.12803.

[38]. PRESHAW, P.M.; BISSETT, S.M. Periodontitis and diabetes [J]. British dental journal, vol. 227, n. $7,2019, \quad$ p. 577-584. https://doi.org/10.1038/s41415-019-0794-5.

[39]. QUINTERO, A.J.; CHAPARRO, A.; QUIRYNEN, $M$., et al. Effect of two periodontal treatment modalities in patients with uncontrolled type 2 diabetes mellitus: A randomized clinical trial. $\mathrm{J}$ Clin Periodontol, vol. 45, n. 9, 2018, p. 10981106. doi:10.1111/jcpe.12991.

[40]. SABHARWAL, A.; GOMES-FILHO, I.S.; STELLRECHT, E.; SCANNAPIECO, F.A.. Role of periodontal therapy in management of common complex systemic diseases and conditions: An update. Periodontol 2000, vol. 78, n. 1, 2018, p. 212-226. doi:10.1111/prd.12226.
[41]. SANTOS, V.R.; LIMA, J.A.; DE MENDONÇA, A.C.; BRAZ MAXIMO, M.B.; FAVERI, M.; DUARTE P.M. Effectiveness of full-mouth and partial-mouth scaling and root planing in treating chronic periodontitis in subjects with type 2 diabetes. J Periodontol, vol. 80, n. 8, 2009, p.1237-1245. doi:10.1902/jop.2009.090030.

[42]. SPRANGER, J.; KROKE, A.; MÖHLIG, M., et al. Inflammatory cytokines and the risk to develop type 2 diabetes: results of the prospective population-based European Prospective Investigation into Cancer and Nutrition (EPIC)Potsdam Study. Diabetes, 52, n. 3, 2003, p. 812817. doi:10.2337/diabetes.52.3.812.

[43]. TEEUW, W.J.; GERDES, V.E.; LOOS, B.G. Effect of periodontal treatment on glycemic control of diabetic patients: a systematic review and meta-analysis. Diabetes Care, vol. 33, n. 2, 2010, p. 421-427. doi:10.2337/dc09-1378.

[44]. TUNES, R.S.; FOSS-FREITAS, M.C.; NOGUEIRA-FILHO, G.D.R. Impact of periodontitis on the diabetes-related inflammatory status. J Can Dent Assoc, vol. 76, n. 35,2010 , p. 1-7. 